\title{
BETWEEN COMMUNITY LAW AND COMMON LAW: THE RISE OF THE CARIBBEAN COURT OF JUSTICE AT THE INTERSECTION OF REGIONAL INTEGRATION AND POST-COLONIAL LEGACIES
}

\author{
SALVATORE CASERTA* \\ MIKAEL RASK MADSEN** \\ I \\ INTRODUCTION
}

Many regarded the creation of the Caribbean Court of Justice (CCJ) in 2005 as the culmination of the Caribbean's long and protracted process toward final independence from its former colonizers. In the words of some insiders, it marked the "closing of the circle of independence" 1 and the "sunset of British colonial rule." Indeed, twelve member states of the Caribbean Community (CARICOM) quickly accepted the Court's jurisdiction ${ }^{3}$ to interpret and apply the Revised Treaty of Chaguaramas (RTC) (2001), which formed the new Caribbean Single Market and Economy. ${ }^{4}$ Formally, the CCJ was thereby almost instantaneously empowered to hear cases involving Caribbean Community law (Community law). The CCJ was also empowered to replace the Judicial Committee of the Privy Council (JCPC) in London-a last court of appeals for civil and criminal cases from the Caribbean and the most visible remnant of the British Empire's former rule over the region. In regard to this jurisdiction,

Copyright (C) 2016 by Salvatore Caserta \& Mikael Rask Madsen.

This article is also available at http://lcp.law.duke.edu/.

* Doctoral Student at iCourts, Faculty of Law, University of Copenhagen.

** Professor of Law and Director of iCourts, Faculty of Law, University of Copenhagen. This research is funded by the Danish National Research Foundation Grant no. DNRF105 and conducted under the auspices of the Danish National Research Foundation's Centre of Excellence for International Courts (iCourts).

1. Duke E. Pollard, The Caribbean Court of Justice: Closing the Circle of INDEPENDENCE 196 (2004).

2. Leonard Birdsong, Formation of the Caribbean Court of Justice: The Sunset of British Colonial Rule in the English Speaking Caribbean, 36 U. MIAMI INTER-AM. L. REV. 197, 227 (2004).

3. More precisely, ten member states accepted the jurisdiction of the CCJ in 2001, and two additional states joined two years later. Although, full member states of CARICOM, the Bahamas and Haiti have not yet ratified the CCJ.

4. Derek O'Brien \& Sonia Morano-Foadi, CARICOM and its Court of Justice, 37 COMMON L. WORLD REV. 334, 334 (2008). 
however, the Court fared less well. To date only four Caribbean countries have accepted the CCJ's appellate jurisdiction: Guyana and Barbados in 2005, Belize in 2010, and Dominica in 2015.

The CCJ's unique double jurisdiction-original over Community law and appellate over other civil and criminal matters-underscores the complex sociopolitical context and transformation of which it is a part. Whereas the CCJ's original jurisdiction over the RTC suggests a new, more judicialized approach to Caribbean integration, the Court's appellate function is intended to repatriate to the Caribbean the development and control over the common law. This combination of globalization and latter-day decolonization is fundamental for understanding the Court's authority. The legal distinction between original and appellate jurisdiction is often blurred during the heated debates surrounding the Court, in which the call for independence clashes with postcolonial anxieties. These post-colonial anxieties are often articulated as concerns that a departure from the former imperial metropolis implies a farewell to the guarantees of a disinterested due process of law that has been an integral part of the fabric of social and political life since British conquest. These anxieties are compounded by the fear that giving up the legal recourse to the JCPC in London might trigger an exodus of foreign investment from the region. ${ }^{5}$ For precisely these reasons, discussions as diverse as Caribbean-specific sensitivities to capital punishment and sovereignty-intruding, cross-border tariff regulations have accompanied the Court's operation since its inception in 2005.

This construction of the CCJ at the crossroads of two different developments is central for the analysis of its authority and highlights the Court's two relatively different constituencies and operational contexts. This article, however, argues that the CCJ's growing authority has increasingly made the Court the institutional intersection for the convergence of these two different paths toward establishing the Caribbean as a legally integrated regional unity. This article's analysis builds on qualitative interviews, conducted mainly in Trinidad \& Tobago, Barbados, and Guyana. Empirical fieldwork used reflexive sociology to explore the broader socio-legal space that has emerged around the CCJ. ${ }^{6}$ This article relies upon forty-one interviews conducted with major stakeholders in the CCJ system, including judges, lawyers, civil servants, private business, and civil society groups.

This interview-based approach combines with the authority theory developed by Alter, Helfer, and Madsen. ${ }^{7}$ The authors focus mainly on three

5. Interview n. 9 (Oct. 23, 2013). See also POLlARD, supra note 1, at 91-93 (detailing the importance of a stable political climate within CARICOM to foreign investors). Citations to an interview list the interviewee's number and the date on which the interview was conducted.

6. For details on this approach, see generally Mikael Rask Madsen, Reflexivity and the Construction of the International Object: The Case of Human Rights, 5 INTERNATIONAL POLITICAL Sociology 259 (2011); Yves Dezalay \& Mikael R. Madsen, The Force of Law and Lawyers: Pierre Bourdieu and the Reflexive Sociology of Law, 8 ANN. REV. OF L. AND SOC. SCI. 433 (2012).

7. This article relies on the definitions of authority laid out in the introduction to this symposium. See Karen J. Alter, Laurence R. Helfer \& Mikael Rask Madsen, How Context Shapes the Authority of 
different types of authority in fact that an international court (IC) might have: narrow, intermediate, and broad authority. In all three cases, the theory assesses authority based on whether the relevant constituencies regard IC decisions as binding and providing impetus for making consequential changes in behavior. In this theoretical model, an IC has narrow authority when the immediate parties of specific disputes recognize the IC's decisions as binding and take consequential steps toward compliance. An IC has intermediate authority when an extended group of practitioners and multiple litigants acknowledge the binding nature of an IC's rulings and act in accordance in words or deed. Finally, an IC has broad authority when a larger legal fieldcomprising, for example, academics, civil society, government officials, and politicians - considers the rulings of an IC as binding sources of law and actively engages in the formation of legal norms' content, based on a priori acceptance of the existence of the IC in question. As this article shows, this theory works well for explaining the authority of the CCJ, which empirically has evolved from narrow authority to intermediate authority. The authority of the Court is currently marked both by growing popular support in some member states and by increasing reluctance in other member states, particularly with regard to the Court's recent free-movement rulings.

The article proceeds in the following way. Part II analyzes the protracted genesis of the CCJ with particular focus on the trajectories of the Court's two main regional contexts-the Caribbean Community and the post-colonial context of Transnational English law and the Privy Council. Part III first discusses the CCJ's initial establishment and its rather narrow authority during the Court's first years of operation. Then, part III turns to address the recent developments in the Court's case law, which indicate an expansion of authority. Among other things, in this last part we focus on a fundamental-rights jurisprudence that has spurred a new popular interest in the Court.

II

The Protracted Genesis of A CARIBBEAn COMMON COURT

Although the CCJ has only been in operation since 2005, the process toward establishing the Court dates back more than a century. In fact, the conception of "Caribbean integration through law" goes back even further. The Caribbean was first assembled as a regional legal entity under British rule and later regionalized under the auspices of CARIFTA and CARICOM. ${ }^{8}$ Although there appears at first glance a historical continuity between the British colonial rule and the launch of regional integration under these regional organizations, the duality of the CCJ's jurisdiction firmly underlines that the Court is by no means a transition from one dimension of integration to the other. On the contrary, the two dimensions of integration coexist to this day as common law and

International Courts, 79 LAW \& CONTEMP. PROBS., no. 1, 2016, at 9-12.

8. See generally ANTHONY PAYNe, THE POLITICAL HistORY OF CARICOM (2008) (recounting transition from British rule to CARIFTA to CARICOM). 
Community law, respectively. ${ }^{9}$ This implies that the integration processes prior to the establishment of the CCJ are not simply historical preliminaries to its establishment, but also key contexts for explaining its relative authority today. These historical precursors to the CCJ are discussed below.

\section{A. The English Passage: Law as Imported Knowledge}

Although many European powers have attempted to control the Caribbean, the British rule of the West Indies is undoubtedly the most significant contextual factor influencing the CCJ. ${ }^{10}$ Generally, British rule implied a degree of legalism that differed from the previous Spanish conquest. If, as argued by Naipaul, Spanish rule was marked by the pragmatic notion of se obedece, per no se cumple (of obeying the law but not following it), ${ }^{11}$ the British Empire introduced a real recourse to English law and to the relatively advanced legal technology of London. This possible recourse and remedy became an integral legal and political factor in the fabric of West Indian society and undoubtedly an important part of its post-colonial heritage. The first proposals for a Caribbean common court were precisely a reaction to the British legal domination. For example, in 1901 a well-known Jamaican newspaper argued that law should be "repatriated" to the Caribbean by a Caribbean Court replacing the JCPC. ${ }^{12}$

At the Montego Bay Conference in 1947, the British took up the idea of a regional Caribbean court of last resort as part of a project for creating a West Indian federation. Motivating this suggestion was the British desire to limit the costs of maintaining its empire. It was a full decade later, however, in 1958, that the project bore fruit with the establishment of the West Indies Federation, which included a Federal Supreme Court. The Federation was operational for only four years, collapsing with the independence of Jamaica and Trinidad \& Tobago in 1962 and of many more Caribbean states shortly thereafter. ${ }^{13}$ Although political nationalism thereby trumped regional integration in the legal arena, ${ }^{14}$ most states nevertheless opted for maintaining appeals to the Privy Council and for membership of the Commonwealth as part of their new

9. Legally, they coexist under the organizations of the CARICOM and the Commonwealth of Nations.

10. Martinique and Guadeloupe remain outside the CCJ's jurisdiction because they are French overseas territories. Among French-speaking Caribbean states, only Haiti is a plausible new party to the CCJ, at least with respect to its original jurisdiction, given that it is a member state of CARICOM. Among the former Dutch colonies, Suriname is a CARICOM member state, and it ratified the Agreement of the CCJ in 2001.

11. VidiadHar Surajprasad NAIPAUl, THE Loss OF Eldorado: A COLONIAL History 15 (2001).

12. POLLARD, supra note 1 , at xi.

13. See generally John Mordecai, The West Indies: The Federal Negotiations (1968) (describing the history of the West Indies Federation).

14. See generally Charles H. Archibald, The Failure of the West Indies Federation, 18 THE WORLD TODAY 233 (1962). 
constitutional arrangements. ${ }^{15}$ With the exception of Guyana, which became a republic and severed ties with the Privy Council in 1970 (yet remained in the Commonwealth), and Grenada, which suspended the appeals to London during the Grenadian revolution between 1979 and 1991, the rest of the Caribbean states kept this transnational legal framework. ${ }^{16}$ It was only in 2005 , when the CCJ first began hearing cases, that Barbados and Guyana opted for having the CCJ as their last court of appeal. ${ }^{17}$ Belize followed suit in 2010 and Dominica in 2015. ${ }^{18}$ The other CARICOM countries retain appeals to the JCPC in London to this day.

This construction of a legal system of independent states with appeals to a primarily English court has had significant impact on the legal profession, the law of the Caribbean, and, ultimately, on the CCJ. For example, the training of lawyers has long been an English cultural transplant, but now it is increasingly performed by local agents trained in the former colonial metropolis. The investment in English law by local elites both before and after independence created an incentive to promote English law as a way of sustaining their own interests. Interviews with the generation of lawyers trained from the 1950 s to the 1970s generally confirm this image of a set of practitioners who learned about the Caribbean as a collective entity in two different, yet ultimately connected, ways. In Oxbridge, in Caribbean debating societies such as the West Indian Society of Oxford, many law students encountered for the very first time the idea of the Caribbean as a united entity. ${ }^{19}$ In addition to imagining the region from the more aloof distance of Oxbridge, many of these young lawyers subsequently came to practice as what some interviewees called "banana boat lawyers" ${ }^{20}$ - a label indicating that trained lawyers were scarce and the larger metropolitan areas of the Caribbean often supplied legal expertise to many of the other island states. The term derives more precisely from the function of the banana boats, which provided the means of transportation for these lawyers-at least until the creation of Caribbean commercial airlines facilitated modern-day air traffic.

To this generation and social grouping of lawyers, the Caribbean emerged culturally and legally out of these different but related legal practices, both in England and throughout the Caribbean basin. Although the lawyers in question

15. Rose-MARIE B. ANTOINE, COMMONWEALTH CARIBBEAN LAW AND LEGAL SYSTEMS 307 (2008).

16. $I d$.

17. Armand de Mestral, The Constitutional Functions of the Caribbean Court of Justice, 1 McGILL J. DisP. RESOL. 43, 65 (2015).

18. Several Eastern Caribbean countries manifested the intention of ratifying the appellate jurisdiction of the CCJ at the fifty-fourth meeting of the OECS in 2012. In 2014, Dominica became the first Eastern Caribbean State to leave the JCPC, at which point it submitted to the appellate jurisdiction of the CCJ. Caribbean Court of Justice, The CCJ Welcomes Dominica to its Appellate Jurisdiction, Media Release No. 6:2015 (Mar. 5, 2015), http://www.caribbeancourtofjustice.org/wpcontent/uploads/2015/03/MEDIA-RELEASE-06-2015.pdf.

19. Interviews n. 9 (Oct. 23, 2013); n. 18 (Oct. 25, 2013); n. 23 (Oct. 30, 2013).

20. Interviews n. 3 (Oct. 21, 2013); n. 1 (Oct. 21, 2013); n. 9 (Oct. 23, 2013); n. 10 (Oct. 23, 2013). 
generally present themselves as Caribbean, they have in most cases not only maintained very close links to the United Kingdom, but also a candid skepticism toward local legal knowledge. These lawyers are best described as "transnational legal elites" 21 whose practices are based on a superior knowledge of English law, close contacts to London chambers, and an ability to solve local problems with transnational solutions. In fact, the connection to the United Kingdom has been used both legally, by bringing cases to the JCPC through their knowledge of English law, and politically, by bringing in senior English barristers (known as Queen's Counsel) to solve local political problems and generally questioning the quality and germaneness of local resources. This connection to the United Kingdom has produced a unique transnational platform for practicing law (and also often politics), which conspicuously plays on post-colonial anxieties with respect to the allegedly superior solutions offered in the former imperial metropolis. Importantly, this dominant group of lawyers long viewed the idea of a regional appellate court with suspicion. It potentially contested their privileges and power by challenging the hegemony of common law made in England yet practiced by this local transnational legalpolitical elite. ${ }^{22}$

It took a major event to transform these perceptions-namely, the JCPC overstepping what the transatlantic (and also the more nationalistic) elites were willing to accept from the former colonial power's legal system. The issue at stake was the death penalty - a widespread punishment during the colonial era preserved by many Caribbean states, but no longer in sync with the standards of contemporary Europe. The key ruling was Pratt and Morgan v. Attorney General of Jamaica, ${ }^{23}$ which resulted in a "near de facto abolition of the death penalty" in the Commonwealth Caribbean. ${ }^{24}$ Drawing largely on European human rights precedents, the JCPC concluded that a delay of more than five years in carrying out a death sentence was an "inhuman and degrading punishment" ${ }^{\prime 25}$ contrary to the Jamaican Constitution. The Privy Council applied the same approach to death penalty appeals from Trinidad \& Tobago and Barbados. This approach placed the established political and legal elites in the three largest Commonwealth Caribbean states in open conflict with the JCPC, which they accused of legislating on behalf of the region.

21. See Niilo Kauppi \& Mikael Rask Madsen, Transnational Power Elites: The New Professionals of Governance, Law and Security, in TRANSNATIONAL POWER Elites: THE NEW PROFESSIONALS OF Governance, LAW AND SECURITy 1, 3-8 (Niilo Kauppi \& Mikael R. Madsen eds., 2013) (defining "transnational legal elites").

22. According to one interviewee, several law firms in Trinidad specialize in cases before the Privy Council. They have generally been opposed to the CCJ for fear of losing clients. Interview n. 28 (Nov. 6, 2013).

23. Pratt and Morgan v. Attorney General of Jamaica [1993] 2 AC 1 (PC) (appeal taken from the Court of Appeal of Jamaica).

24. Laurence R. Helfer, Overlegalizing Human Rights: International Relations Theory and the Commonwealth Caribbean Backlash against Human Rights Regimes, 102 COLUM. L. REV. 1832, 1879 (2002).

25. Pratt and Morgan [1994] 2 AC gI 64. 
This situation created a unique window for the CCJ's establishment as an indigenous court of appeal. Yet ten years later, when the CCJ eventually began to hear cases, only Barbados chose to leave the Privy Council behind. In contrast, Trinidad \& Tobago exercised its wrath on the Inter-American human rights tribunals (which issued rulings also disfavoring the death penalty) by withdrawing from the American Convention on Human Rights in 1998, but it remained under the JCPC's jurisdiction. ${ }^{26}$ Further demonstrating the Court's growing importance, Jamaica actually passed three bills in 2004 that made the CCJ its highest court. ${ }^{27}$ Although the JCPC subsequently struck down these bills as they implied a significant alteration in the state's hierarchical court structure that required a constitutional amendment, a majority in Jamaica's parliament clearly supported the CCJ over the JCPC. ${ }^{28}$

There was however also a visible reverse effect of linking the establishment of the CCJ to death row. Even before the CCJ formally opened, a new set of critics tarred the tribunal as a "hanging court" specifically formed to ensure the continuous use of capital punishment in the Caribbean. ${ }^{29}$ This put the nascent Court in the difficult situation of not only having to establish its authority on CARICOM law, but also finding a solution to the question of capital punishment that both appeased its advocates and met international human rights standards.

\section{B. The Caribbean Passage: "Caribbean Integration through Law"}

The Caribbean's integration through law provides another regional context relevant to the eventual development of the CCJ's jurisprudence. During British rule, both locals and the empire supported attempts to establish local higher education - in part to limit the costs of studies abroad for students. ${ }^{30}$ The opening of the University College of the West Indies in 1948, now the University of the West Indies (UWI), eventually produced an alternative path to that of the Oxbridge-educated elite: a Caribbean higher education. The UWI Law Faculty was created in 1970 and was followed by the establishment of a number of local law schools certified to issue legal diplomas in Jamaica (1973), Trinidad \& Tobago (1973), and The Bahamas (1998). ${ }^{31}$ A different social

26. A limited attempt was made by Trinidad \& Tobago to accept the CCJ's jurisdiction only for matters of criminal law; other cases would go to the JCPC. The plan, however, has not been implemented. See generally POLLARD, supra note 1 (describing the formation and development of the CCJ).

27. The Caribbean Court of Justice Act 2004: Act 20 and 21 of 2004 and the Judicature Act, Act 19 of 2004.

28. Independent Jamaica Council for Human Rights (1998) Ltd. \& Ors v. Marshall-Burnett and Anor [2005] 2 A.C. 356 (PC) 372 (appeal taken from the Court of Appeals of Jamaica).

29. Hugh RAwlins, THE CARIBBEAN COURT OF Justice: THE History AND ANALYSIS OF THE DEBATE 28 (2000); David Simmons, The Caribbean Court of Justice: A Unique Institution of Caribbean Creativity, 29 NOVA L. REV. 171, 186 (2005).

30. ANNE SPRY RUSH, BONDS OF EMPIRE: WEST INDIANS AND BRITISHNESS FROM VICTORIA TO DECOLONIZATION 21-46 (2011).

31. Legal studies were also offered at the University of Guyana. 
grouping of lawyers emerged from the UWI law campuses, one more radically attuned to the Caribbean, a fact in part attributable to the political and historical conjunctures of the 1970s. Importantly, however, the locally trained lawyers were not (and are not) turned against English law. The common law was not only part of their curriculum but also part of the law of the Caribbean.

Although many among this new group of lawyers pursued LL.M.s in the United Kingdom, they shared neither the transnational legal elite's vested interests in English law nor their relative reluctance toward genuine Caribbean law. ${ }^{32}$ In important ways, the UWI became the laboratory for a different kind of Caribbean integration. More similar to the practices of the "banana boat lawyers," who practiced law by traveling between surrounding islands, than to the Oxbridge campus, these students were obliged to move around the Caribbean to get their diplomas, which in itself contributed to the creation of a collective identity. ${ }^{33}$ Moreover, the students were introduced to elements of Caribbean law from the different regional states, effectively training them to become a new generation of "banana boat lawyers." Adding classes on Caribbean history and culture, the result was unmistakably Caribbean. ${ }^{34}$ Despite this movement toward Caribbean law and away from English law, the institutional recognition of the significance of this movement did not occur until years later. For example, the UWI only first offered a class on the particular topic of Caribbean law and integration in the early 2000s, which coincided with the opening of the CCJ. Similarly, the first systematic textbook on the subject did not appear until $2014 .^{35}$

This very gradual emergence of Community law did not result from a lack of interest among these locally trained lawyers. Rather, it was largely an effect of CARICOM's slow development, ${ }^{36}$ particularly with respect to its law. Generally, the development of the Caribbean community has largely unfolded in reaction to major external changes often involving the United Kingdom. For example, when the United Kingdom initiated the process of becoming a member of the European Community in the early 1960s, it was clear to many Caribbean leaders that late-colonial special treatment would soon be a thing of the past. $^{37}$ These leaders proved prophetic; the Caribbean Free Trade Association (CARIFTA) was created in the mid-1960s. Less than a decade later, in 1973-when the United Kingdom formally joined the European Community-it was transformed into the more politically ambitious Caribbean

32. Interview n. 43 (Dec. 4, 2014).

33. Indeed, this had a somewhat similar effect to the EU Erasmus programs in Europe. See, e.g., Bruno De Witte, European Union Law: A Unified Academic Discipline?, in LAWYERING EUROPE: European LAW as a Transnational Social FiEld 101, 109 (Antoine Vauchez \& Bruno de Witte eds., 2013).

34. Interview n. 24 (Oct. 31, 2013).

35. The textbook is DAVID BERRY, CARIBBEAN INTEGRATION LAW (2014).

36. See generally CHRISTOPH MÜllerleile, CARICOM INTEGRATION: PROGRESS AND HuRDLES: A EUROPEAN VIEW (1996) (detailing the slow development of CARICOM).

37. Payne, supra note 8 , at 14 . 
Community and Common Market. A third major transformation occurred at the end of the Cold War, when the region was once again forced to further reorganize and strengthen integration. ${ }^{38}$ The Single European Market jeopardized what was left of preferential economic treatment of Caribbean states by the United Kingdom. The favorable trade conditions granted under the Caribbean Basin Initiative ${ }^{39}$ were equally threatened by the NAFTA agreement between Canada, the United States, and most importantly, Mexico.

Inspired by these changes in the world economy, a commission chaired by the former Commonwealth Secretary-General "Sonny" Ramphal was established. ${ }^{40}$ The Commission produced a report that prioritized the legalization of the CARICOM. ${ }^{41}$ The Commission presented a number of proposals, including: the creation of an EU-inspired commission vested with executive and administrative powers, the introduction of a regional legislative system, the effective realization of the Common Market and Single Economy, and importantly, the creation of the CCJ. About the latter, the Ramphal Commission noted: "[T] he case for the CARICOM Supreme Court, with both a general appellate jurisdiction and an original regional one, is now overwhelming - indeed it is fundamental to the process of integration itself." This plan unsurprisingly found support on the UWI campuses and among its alumni. ${ }^{43}$ Other legal and political elites, however, many of whom had made the passage through England, were less enthusiastic. The idea of an executive commission was flat-out rejected. Only the proposals for setting up a regional court and for creating the Common Market and Single Economy survived. The eventual establishment of the Court was effectively enabled by a combination of those arguing for the urgency of reforming the CARICOM in light of global economic changes and the more nationalistic and sovereignty-craving groups that had opposed a supranational executive. As analyzed above, however, the Privy Council also helped pave the road for the CCJ's palatability to both the nationalistic and transatlantic elites. The result was the current CCJ with double jurisdiction: as highest court over the interpretation of the Revised Treaty of Chaguaramas and as final court of appeal for civil and criminal cases.

38. Caribbean Community Secretariat, Grande Anse Declaration and Work Programme for the Advancement of the Integration Movement, at 1 (July 1989).

39. The Caribbean Basin Initiative was a unilateral program of the United States initiated by the Reagan Administration regarding Caribbean and Central American countries. It was established in 1984, and its main goal was to provide several tariff and trade benefits to the Caribbean and Central American countries in the commerce with the United States in order to fight the spread of socialism and communism within the region. W. H. Griffith, CARICOM Countries and the Caribbean Basin Initative, 17 LATIN AM. PERSP, 33, 33 (1990).

40. Anthony Payne, Statesman of the West Indies, in SHRIDATH RAMPHAL: THE COMMONWEALTH AND THE WORLD 95-112 (2008).

41. WEST INDIAN COMMISSION, TIME FOR ACTION: REPORT OF THE WEST INDIAN COMMISSION 498 (2d ed. 1992).

42. Id.

43. In fact, this legal model was already identified in 1972 in a report by the Organization of Commonwealth Caribbean Bar Association, which argued that the solution was to create a court with a double competence. POLLARD, supra note 1, at 2. 
III

\section{IN SEARCH OF AUTHORITY: THE CCJ FROM NARROW TO BROAD AUTHORITY}

The above analysis has considered the different and opposing forces at play regarding the creation of the $\mathrm{CCJ}-$ the post-colonial transformation, the dominant transatlantic production of law, and the evolving Caribbean legal milieus at the UWI. These different forces produced a relative schism between common law and Community law, one that eventually translated into the creation of the CCJ with a dual jurisdiction. The Court coming into operation therefore inevitably involved two different operational contexts that have considerably different trajectories and agency. The following discussion analyzes the gradual expansion of the CCJ's authority, from its initial rulings on free market law and capital punishment, to its most recent case law, which has extended the CCJ's authority by means of a new fundamental-rights jurisprudence with constitutional implications. The emphasis is, however, on the original jurisdiction of the Court.

\section{A. Overcoming Socio-Political Constraints through Judicial Independence}

The initial challenges faced by the CCJ reflected the limited legalization of Caribbean integration and the still-ambiguous relation to London notwithstanding the death row issue. Thus, the nascent Court had to both affirm itself within the area of CARICOM law and develop a solution for the outstanding issue of capital punishment that simultaneously satisfied its advocates and international human rights standards-all while avoiding the reputation of a "hanging court." ${ }^{44}$ This challenge reflected itself practically in all preliminary actions of the emerging Court, which sought to secure its independence legally, politically, and financially. The CCJ's pursuit of independence had significant structural results, namely: the appointment of the first President of the Court, the appointment of the other judges, and the creation of a trust fund for administering the financial resources of the Court.

Whereas IC presidents are mostly elected by the collegium of judges, in the case of the CCJ, the President was appointed before the other judges by the Heads of States following recommendations of an expert commission. ${ }^{45}$ Insiders were well aware of the political and symbolic implications of this unique appointment procedure. Moreover, the selection also had real consequences, as the President's appointment resulted in automatic designation as the Chairman of the Regional Judicial and Legal Services Commission, the organ vested with the power to appoint the other judges. ${ }^{46}$ Given the influence of this position and the generally suspicious attitude of Caribbean legal professionals toward the

44. Simmons, supra note 29 , at $186-88$.

45. Article VI (6) of the Agreement establishes that the President is appointed by a qualified majority vote of three quarters of the contracting parties after the recommendation of the Regional Judicial and Legal Services Commission. Agreement Establishing the Caribbean Court of Justice art. VI (Feb. 14, 2001) [hereinafter Agreement].

46. Id. art. VII. 
local judiciary, the appointment of the first President constituted a first crucial step for the establishment of the CCJ and its authority.

In 2004, the Conference unanimously nominated Michael de la Bastide, ${ }^{47}$ a well-known Pan-Caribbean lawyer, former President of the Law Association of Trinidad and Tobago and former Chief Justice of Trinidad \& Tobago. ${ }^{48}$ De la Bastide embodied many of the virtues of the old legal elite, but he was also a modern judge. His connections to the United Kingdom were immaculate: he graduated top of his class at Oxford in 1959-60, he became a member of Gray's Inn in London in 1956, and he eventually became a member of the Privy Council in 2004-less than three weeks before taking office as the President of the CCJ. In Trinidad, de la Bastide's career was equally impressive and involved all the key venues of the legal (and political) elite: he had been in private practice as a Queen's Counsel, served in public office as an independent Senator, been a representative on several important government commissions, served as the Crown Counsel in the office of the Attorney-General, and served as the Chief Justice of Trinidad \& Tobago (1995-2002). ${ }^{49}$

Publicly outspoken, de la Bastide had also made a name for himself as an ardent defender of judicial independence. In fact, before being appointed to the CCJ, de la Bastide had already fought for the independence of the judiciary in Trinidad \& Tobago for decades. Particularly, his public clashes over the issue with the then Attorney-General Ramesh Maharaj were known throughout the region (and were only settled when Lord MacKay was brought in from London). ${ }^{50}$ The appointment of de la Bastide thus signaled the impartiality and independence of the CCJ. As President of the CCJ, he chaired the Regional Judicial and Legal Services Commission, which was created to insulate judicial appointments from political pressure. ${ }^{51}$ The independence of the CCJ was further enhanced by the fact that the Court's finances were placed in an independent fund of some 100 million U.S. dollars, ${ }^{52}$ and managed by an independent board of trustees. ${ }^{53}$ Operating from the vantage point as both President of the nascent CCJ and Chairman of the appointment committee, de la Bastide argued that the Caribbean should aspire to have "a world class court." ${ }^{, 54}$ There were plenty of applicants for seats on the bench and twelve were eventually interviewed. The collegium of judges selected struck a fine balance

47. Simmons, supra note 29 , at 193 .

48. Interview n. 3 (Oct. 21, 2013).

49. Judges of the CCJ: Past President-The Right Honourable Mr. Justice Michael de la Bastide, THE CARIBBEAN COURT OF JUSTICE, http://www.caribbeancourtofjustice.org/about-the-ccj/judges/ past-president-\%E2\%80\%93-the-rt-hon-mr-justice-michael-de-la-bastide (last visited Dec. 29, 2015).

50. Interviews n. 9 (Oct. 23, 2013); n. 20 (Oct. 28, 2013).

51. Agreement, supra note 45 , art. 6 .

52. Birdsong, supra note 2, at 211.

53. This had been decided in 2002 at the Twenty-third Meeting of the Conference precisely with the goal of enhancing its impartiality and independence as a response to critics of the local judiciary. Agreement Establishing the Caribbean Court of Justice Trust Fund (Jan. 12, 2004) [hereinafter The Trust Fund Agreement].

54. Interview n. 3 (Oct. 12, 2013). 
between judicial and academic experience, national and international experience, and geographic distribution. More precisely, the bench represented a microcosm of the complexities faced by the Court, including the difference between transatlantic and Caribbean constructions of the region, common law and Community law, and the old and the new elites of Caribbean law. ${ }^{55}$

\section{B. Limits by Institutional Design}

The careful selection of the CCJ bench, and the underlying strategy for maximizing both independence and legitimacy, did not change the fact that the Court faced a number of challenges emanating from its design. Most of these were linked to the overall reluctance of Caribbean States to relinquish sovereignty. ${ }^{56}$ Although the RTC introduced some changes to the region's integration system, ${ }^{57}$ CARICOM remained mostly a system controlled by member states and not a supranational organization. Concretely, the Community did not have legislative powers. Consequently, there was no immediate secondary legislation applicable within the member states. ${ }^{58}$ The legal mandate of the CCJ was thus limited to interpreting and applying the RTC itself. ${ }^{59}$ CARICOM's interstate emphasis translated into restrictions on access to the Court. Whereas the Ramphal Commission had proposed the establishment of an Executive Secretariat modeled on the European Commission to overcome

55. In addition to President de la Bastide, the first bench included judges with significant experience in Caribbean Community law such as Duke Pollard of Guyana, who had studied at the University of London and, among other things, had been the Legal Advisor of the Commonwealth Secretariat as well as the CARICOM Secretariat. He also played a key role in the negotiations and drafting surrounding the treaties for issues related to the CCJ. Other judges were leading experts of Caribbean common law and national laws: Rolston Nelson of Trinidad \& Tobago, who, after studying at the University of Oxford and University of London, practiced and taught in Jamaica and Trinidad \& Tobago; Adrian Saunders of St. Vincent and the Grenadines, who studied at UWI and at the Hugh Wooding Law School of Trinidad \& Tobago before being appointed Chief Justice of the Eastern Caribbean Supreme Court; and Desiree Bernard of Guyana, who studied law at the University of London before being appointed as Chief Justice and Chancellor of the Judiciary of Guyana. In addition to judges knowledgeable of Community law and national Caribbean law, two more judges, experienced with civil and European law and business law, including trust law, completed the bench: Jacob Wit of the Netherlands had a law degree from the Vrije Universiteit of Amsterdam and had been a judge at the Joint Court of Justice of the Netherlands, Antilles, and Aruba and was clearly intended to be the civil-law and EU law judge on the court; and David Hayton of England, who received his law degree from the Newcastle University before serving as law professor and Dean of the Law Faculty at King's College, London and combined academia and practice as a leading authority on the law of trusts. Judges of the Caribbean Court of Justice, THE CARIBBEAN COURT OF JUSTICE, http://www.caribbean courtofjustice.org/about-the-ccj/judges.

56. See generally BERRY, supra note 35; O'Brien \& Foadi, supra note 4, at 346.

57. The creation of the CCJ, the Common Market, and the Single Economy introduces elements not in full control of the states. The RTC also softened the requirement of unanimity for the substantive decisions of the Conference of the Heads of Government. O'Brien \& Foadi, supra note 4, at $337-39$.

58. O'Brien \& Foadi, supra note 4, at. 342-43.

59. Derek O'Brien \& Sonia Morano-Foadi, The Caribbean Court of Justice and Legal Integration within CARICOM: Some Lessons from the European Community, 8 L. \& PRAC. OF INT'L CTS. \& TRIBUNALS 399, 404 (2009). 
the serious implementation problems faced by the CARICOM, ${ }^{60}$ the RTC included only a modest expansion of the Secretariat's powers, such as the right of the Secretary-General to submit proposals to the organs of the Community and to legally represent it ${ }^{61}$ including before the CCJ. However, his power remained constrained. For example, the Secretariat did not have the right to initiate legal proceedings before the $\mathrm{CCJ}$ on behalf of private parties but instead only had the right to serve as a representative for the Community. ${ }^{62}$

Other institutional features of the CARICOM also limited the operational space of the CCJ. Notably, the wording of the Article $222 \mathrm{RTC}^{63}$ which regulates the conditions that individuals need to meet for accessing the Court, was drafted in way that appeared to limit private access and to establish the $\mathrm{CCJ}$ as mainly an interstate court to satisfy the involved governments' craving for sovereignty. ${ }^{64}$ Two interviewees, both close to the drafting process, confirmed that Article 222 was strategically drafted as an open-ended article, with either the hope-according to one interviewee-or with the convincement-according to the other-that the future judges of the CCJ would interpret the Article in an extensive way. ${ }^{65}$ As discussed below, Article 222(c) in particular created several problems in the first cases reaching the Court and probably constrained the flow of subsequent cases as well.

There are other relevant access provisions, notably Article 211 RTC.

60. West Indian Commission, supra note 41, at 501-02.

61. Treaty Establishing the Caribbean Community arts. 24(a), (g), July 4, 1973, http://www.cari com.org/jsp/community/original_treaty-text.pdf [hereinafter Treaty].

62. Regarding the difficulties of the CCJ caused by the absence of a European Commission-like commission, see O'Brien \& Morano-Foadi, supra note 4, at 340.

63. Article 222 RTC regulates the Locus Standi of private entities before the Court. The text of the Article proceeds as follows:

Persons, natural or juridical, of a Contracting Party may, with the special leave of the Court, be allowed to appear as parties in proceedings before the Court where:

(a) the Court has determined in any particular case that this Treaty intended that a right or benefit conferred by or under this Treaty on a Contracting Party shall ensure to the benefit of such persons directly; and

(b) the persons concerned have established that such persons have been prejudiced in respect

of the enjoyment of the right or benefit mentioned in paragraph (a) of this Article; and

(c) the Contracting Party entitled to espouse the claim in proceedings before

the Court has:

(i) omitted or declined to espouse the claim, or

(ii) expressly agreed that the persons concerned may espouse the claim instead of the

Contracting Party so entitled; and

(d) the Court has found that the interest of justice requires that the persons be allowed to espouse the claim.

Treaty, supra note 61, art. 222.

64. See interview n. 15 (Oct. 24, 2013); see also Desiree P. Bernard, Olive Trotmans Memorial Lecture Series: The Caribbean Court of Justice and Its Relationship with the Caribbean Single Market Economy (2006); Duke E. Pollard, The Caribbean Court of Justice: Who Stands to Gain?, in FifTeEnTh Public Lecture of the Management Institute of National DeVelopment (MIND) (2008).

65. Interviews n. $35 \& 36$ (Dec. 5, 2014). 
Although it formally grants broad access to the CCJ ${ }^{66}$ it is more limited in practice. In fact, although the main access points to the Court are via applications by member states and by the Community against member states, these avenues are rarely used for sociopolitical reasons. Caribbean governments have a tacit understanding not to sue each other before the CCJ and to instead resort to "informal" ways of solving conflicts. ${ }^{67}$ Likewise, an application by the Community against member states is highly unlikely. As noted by lawyers close to the Secretariat, the Secretary-General is highly constrained in the exercise of this function as guardian of the community because the position is perceived as representing the member states, not as opposing them. ${ }^{68} \mathrm{~A}$ third access point to the $\mathrm{CCJ}$, in addition to applications by member states and by the Community against member states, is comprised of references from national judges. But this access point has yet to produce its first case. ${ }^{69}$ The specialized literature on the CCJ and the authors' interviews generally suggest that the absence of references by national judges is due to both general lack of knowledge about the Court and the uncertainties of the role that CARICOM Community law plays in national legal systems. ${ }^{70}$

The practical result of these institutional design features was that the initial development of Community law litigation came to depend on direct applications from private litigants. ${ }^{71}$ The interest of private actors in using the CCJ was however somewhat constrained by the limited knowledge of the Court's original jurisdiction. ${ }^{72}$ In addition, many private companies feared they would face retaliation if they sued the states in which they wanted to do business. ${ }^{73}$ Some of the same issues impacted the CCJ's appellate jurisdiction. Above all, the lingering reluctant attitude toward the CCJ by the transatlantic

66. Article $211 \mathrm{RTC}$ regulates the access to the Court and proceeds as follows:

Subject to this Treaty, the Court shall have compulsory and exclusive jurisdiction to hear and determine disputes concerning the interpretation and application of the Treaty, including:

(a) disputes between the Member States parties to the Agreement;

(b) disputes between the Member States parties to the Agreement and the Community;

(c) referrals from national courts of the Member States parties to the Agreement;

(d) applications by persons in accordance with Article 222.

Treaty, supra note 61, art. 211.

67. O'Brien \& Morano-Foadi, supra note 4, at 347.

68. BERRY, supra note 35, at 404.

69. From our interviews, it appears however that attempts have been made at least on two occasions.

70. O'Brien \& Morano-Foadi, supra note 59, at 425. Interviews n. 9 (Oct. 23, 2013); n. 28 (Nov. 6, 2013).

71. The Court itself recognized the central role of private parties when it acknowledged that " $[\mathrm{t}] \mathrm{he}$ [Common Market and Single Economy] is intended to be private sector driven." TCL v. Guyana, App. No. AR 1 of 2008 (Original Jurisdiction), Caribbean Court of Justice [CCJ], II 13 (Jan. 15, 2009).

72. Interview n. 9 (Oct. 23, 2013).

73. Interview n. 19 (Oct. 26, 2013); see generally James Thuo Gathii, Variation in the Use of Subregional Integration Courts between Business and Human Right Actors: The Case of the East African Court of Justice, 79 LAW \& CONTEMP. PROBS., no. 1, 2016, at 47-48 (describing a comparable situation in East Africa). 
legal elites, in combination with the foot-dragging approach of the member states with regard to severing ties with the Privy Council, limited the operational space of the CCJ.

\section{C. "We Were Waiting, We Were Hoping": The Caribbean Court (Finally) in Action}

The CCJ's initial challenges in developing its authority were two-fold. On the one hand, the judges needed to overcome the Byzantine wording of Article 222 to give private litigants access under the Court's original jurisdiction. On the other hand, as to the appellate jurisdiction, the judges had to strike a very fine balance on capital punishment to ensure that the Court was neither perceived as a "hanging court" nor as a local epigone of the Privy Council. Yet to take any action, the $\mathrm{CCJ}$ depended on cases arriving. It was a waiting game. In the words of one judge at the time, "We were waiting, we were hoping [that someone would file an application]." ${ }^{, 74}$ The first appeals to arrive were from Barbados in $2005 .{ }^{75}$ Original jurisdiction suits were not filed until 2008. ${ }^{76}$

The first case of importance to the establishment of the Court's appellate jurisdiction authority was Attorney General v. Joseph and Boyce. ${ }^{77}$ In this judgment, the CCJ established two key principles. First, the Court stated that its role was neither to ignore nor to be bound by the jurisprudence of the JCPC. Instead, its task was to reexamine the precedents of the JCPC and to outline the basic features of the approach that the CCJ would take in addressing similar issues. $^{78}$ Second, the Court explained that the jurisprudence of the JCPC on death penalty was only partly correct and added its own view on the issue. ${ }^{79}$ Thus the Court demonstrated its capability to impose itself as the main interpreter and creator of a genuinely Caribbean jurisprudence. With this line of argument, the Court managed to reject charges that the CCJ would either be a "hanging court" or that it would uncritically follow the JCPC. In the period between 2005 and 2015, 143 cases were filed under the appellate jurisdiction. ${ }^{80}$ This relatively high number of cases suggests that the Court was almost

74. Interview n. 3 (Oct. 21, 2013).

75. Barbados Rediffusion Serv. Ltd. v. ASHS Mirchandani Ram Mirchandani McDonald Farms Ltd., App. No. AL 0001 of 2005 (Appellate Jurisdiction), Caribbean Court of Justice [CCJ] (Oct. 26, 2005).

76. Trinidad Cement Ltd. TCL Guyana, Inc. v. The Co-operative Republic of Guyana, App. No. AR 1 of 2008 (Original Jurisdiction), Caribbean Court of Justice [CCJ] (July 22, 2008).

77. Attorney General v. Joseph and Boyce, Appeal No. CV 2 of 2005 (Appellate Jurisdiction), Caribbean Court of Justice [CCJ] (Nov. 8, 2006).

78. Id. II 17.

79. Id. II 126.

80. The cases deriving from Barbados are mainly appeals regarding convictions for murder and relative conversion of the death penalty in incarceration, defamation, transfer of land and property, delays in carrying out trials and judgments, as well as other procedural issues. Cases from Guyana concern mainly employment issues, removal of public officers, land rights, and disrespect of debentures. As to Belize, the cases presented have concerned corruption of public officials, constitutionality of laws, tax privileges, issues related to foreign arbitration, and land rights. THE CARIBBEAN COURT OF JUSTICE, http://www.caribbeancourtofjustice.org/ (last visited Dec. 29, 2015). 
immediately accepted as an authoritative forum. Although the cases concerning the appellate jurisdiction primarily derived from the three countries that had first ratified the Court's appellate jurisdiction domestically, the case flow had a legitimizing effect even outside of these countries.

This became evident in 2008 when the CCJ received the first case under its original jurisdiction. The case was emblematic of the Court's narrow authority at this point regarding Community law. The applicant was a Pan-Caribbean company, Trinidad Cement Limited (TCL), whose CEO, Dr. Rollin Bertrand, had insider knowledge of the Court from his position as the Chairman of the CCJ's Trust Fund to which he had been appointed in his capacity as President of the Caribbean Association of Industry and Commerce. ${ }^{81}$ This intimacy caused heated debates in the press when President Jagdeo of Guyana openly accused Bertrand of abusing of his position and called upon all CARICOM governments to look into the matter. ${ }^{82}$ But this strategy of delegitimization fell somewhat flat, as Prime Minister Golding of Jamaica two weeks later announced that Jamaica was satisfied with the independence of the CCJ and rather than question the CCJ, his country would seek to allow for the Court's appellate jurisdiction. ${ }^{83}$ Basically, the spillover effect of the otherwise geographically limited appellate jurisdiction practices was that it gave authority to the Court in Community law matters as well. Moreover, besides venting the latent frustrations and different perception of regional judicial oversight and more generally the role of the Court, the cases filed by TCL contributed significantly to the launch of the CCJ's original jurisdiction.

Although Bertrand obviously benefitted from insider knowledge of the CCJ, his filing of the TCL case before the CCJ had its own legal and commercial rationale. In the words of a spokesperson of the applicant, the choice of venue was mainly the result of a "frustration deriving from CARICOM inefficiencies, ${ }^{\prime 4}$ which was shared among a number of Caribbean companies.

There was an expectation that as soon as the Court was established and set up, eight or nine cases would come immediately based on the frustration expressed by some companies. We were not unique. We just got into [it] quickly because in our view our interest was threatened by Guyana and by the behavior of COTED [Council for Trade and Economic Development]... A lot of people were afraid of suing governments .... I thought: there is finally a mechanism of redress, let's use it.

81. Interview n. 19 (Oct. 26, 2013).

82. See, e.g., Regional Heads Concerned over Link between CCJ Trust Fund and TCL, STABROEK NEws (Guyana) (Oct. 13, 2009), http://www.stabroeknews.com/2009/archives/10/13/regional-headsconcerned-over-link-between-ccj-trust-fund-and-tcl/.

83. Moreover, the TLC CEO had been transparent about the potential conflict of interest and had a lawyer assess the situation before filing. TCL Disturbed by President Jagdeo's 'Influence' Statement, STABROEK NEwS (Guyana) (Oct. 16, 2009), http://www.stabroeknews.com/2009/archives/10/16/tcldisturbed-by-president-jagdeo $\%$ E2\% $80 \% 99$ s- $\%$ E2\% $80 \% 98$ influence $\%$ E2\% $80 \% 99$-statement/.

84. Interview n. 19 (Oct. 26, 2013).

85. Interview n. 19 (Oct. 26, 2013). For support of the interviewee's statement on the likelihood of more lawsuits at this point please see NAMILCO May Move to Caribbean Court over 'Dumping' of Trinidad Flour on Local Market, StABroek News (Guyana) (Apr. 25, 2008), http://www.stabroeknews.com/2008/business/04/25/namilco-may-move-to-caribbean-court-over- 
In the period from 2008 to 2012, TCL filed three cases (the first of which was filed together with one of the company's Guyana branches (TGI)): one against the state of Guyana ${ }^{86}$ one against the Community (CARICOM) ${ }^{87}$ and one against the Competition Commission of the Community. ${ }^{88}$ Collectively, these cases offered the Court the possibility of ruling on three highly central issues for the development of the jurisprudence of the Court: private access, state liability, and damages.

Of these three cases, the case against Guyana is the most important because it directly concerned a member state's obligation under Caribbean Community law. In that case, TCL and TGI claimed that Guyana had arbitrarily and unilaterally suspended the Common External Tariff on the imports of cement from outside the CARICOM, thereby violating the RTC and causing economic damages to the two companies. ${ }^{89}$ During the application for special leave, ${ }^{90}$ the judges focused on Article 222(c) RTC. The interpretive issue they faced was whether a private party was allowed to sue its own state. Such a right was not expressly recognized by the Article, which, in fact, seemed to suggest that private parties may only appear before the CCJ if their home country has either omitted or declined to present the claim itself, or where the state expressly agreed that the specific private person may present the claim in its place. ${ }^{91}$

The Court's interpretation gave particular attention to the rationale behind Article 222. The Court reasoned that that the RTC did not expressly indicate that the member states intended to prohibit private entities from bringing proceedings against their own state. ${ }^{92}$ The Court further stated that denying such a right would affect not only companies incorporated in member states that had violated the RTC-such as the case at bar-but it would also discriminate against citizens' access to justice on the grounds of their nationality. ${ }^{93}$ The Court thus granted leave to TCL and TGI under Article 222. ${ }^{94}$

$\%$ E2\% $80 \% 98$ dumping $\%$ E2\%80\%99-of-trinidad-flour-on-local-market/.

86. TCL v. Guyana, supra note 71; Trinidad Cement Ltd. TCL Guyana, Inc. v. The Co-operative Republic of Guyana,App. No. OA 2 of 2009 (Original Jurisdiction), Caribbean Court of Justice [CCJ] (Feb. 27, 2009).

87. TCL v. CARICOM, App. No. AR 3 of 2008 (Original Jurisdiction), Caribbean Court of Justice [CCJ] (Feb. 5, 2009); TCL v. CARICOM, App. No. OA 1 of 2009 (Original Jurisdiction), Caribbean Court of Justice [CCJ] (Aug. 10, 2009).

88. TCL v. The Competition Commission, App. No. OA 1 of 2012 (Original Jurisdiction), Caribbean Court of Justice [CCJ] (Nov. 12, 2012).

89. TCL v. Guyana, App. No. AR 1 of 2008 (Original Jurisdiction), Caribbean Court of Justice [CCJ], Il 12 (Jan. 15, 2009).

90. Article 222 RTC establishes that private parties need to obtain special leave from the Court before being admitted to present the merits of a case. Treaty, supra note 60, art. 222.

91. Guyana, App. No. AR 1 of 2008 (Original Jurisdiction), III 23, 36.

92. Id. II 40.

93. Id. IIII 40,42 .

94. Id. II 48. 
Commenting on the case and more generally the early interpretive strategies of the Court, one leading judge summarized the Court's dynamic-if not activist—approach, saying,

I think there was a strong impulse toward adopting a dynamic approach. I suppose it is part of the human nature that having given the opportunity to make a difference, and to give life to this document which served a purpose that we all supported [the Revised Treaty], it seemed normal to not let the letters of the law frustrate you.

The CCJ was, in other words, not satisfied with simply attracting cases; it was also ready to give life to the idea of Community law under the RTC. The Court, however, was also fully aware of not overstepping its boundaries of what the member states would accept when it turned to the merits of the case, which focused on two primary issues: whether the RTC recognized the principle of member-state liability and whether TCL had concrete proof of its alleged loss. ${ }^{96}$ By drawing a parallel between the interpretation that the European Court of Justice (ECJ) had given of Article 5 of the Lisbon Treaty ${ }^{97}$ in Francovich $v$. Italy $^{98}$ and the text of the Article $9 \mathrm{RTC},{ }^{99}$ the $\mathrm{CCJ}$ recognized the existence of the principle of member-state liability within CARICOM law. The Court thus found Guyana in violation of the RTC, but it did not grant any damages because TCL and TGI had failed to meet their burden of proof. ${ }^{100}$

This approach to adjudicating emerging community law resembles very much how both the ECtHR and the ECJ operated in their early jurisprudence of the 1950s and 1960s. As noted by Alter, "[T]he early jurisprudence of the ECJ shows clear signs of caution. Although bold in doctrinal rhetoric, the ECJ made sure that the political impact was minimal in terms of both financial consequences and political consequences."101 Madsen has more generally

95. Interview n. 3 (Oct. 21, 2013).

96. TCL v. CARICOM, App. No. AR 3 of 2008 (Original Jurisdiction), Caribbean Court of Justice [CCJ] (Feb. 5, 2009), III 19, 24-31.

97. Article 5 of the EEC states:

Member States shall take all general or particular measures which are appropriate for ensuring the carrying out of this Treaty or resulting from the acts of the institutions of the Community They shall facilitate the achievement of the Community's aims.

They shall abstain from any measure which could jeopardise the attainment of the objectives of this Treaty.

Treaty Establishing the European Economic Community art. 5, Mar. 25, 1957, http://www.ab .gov.tr/files/ardb/evt/1_avrupa_birligi/1_3_antlasmalar/1_3_1_kurucu_antlasmalar/1957_treaty_establish ing_eec.pdf.

98. Case C-6/90, Francovich v. Italy, 1991 ECRI-5357.

99. Article 9 RTC that provides that member states shall

take all appropriate measures, whether general or particular, to ensure the carrying out of obligations arising out of this Treaty or resulting from decisions taken by the Organs and Bodies of the Community. They shall facilitate the achievement of the objectives of the Community. They shall abstain from any measures which could jeopardize the attainment of the objectives of this Treaty.

Treaty, supra note 61, art. 9.

100. CARICOM, App. No. AR 3 of 2008 (Original Jurisdiction), IIII 32-34.

101. Karen J. Alter, Who Are the "Masters of the Treaty"?: European Governments and the 
theorized this strategy of interpretation in terms of "legal diplomacy" and shown how the ECtHR in its early jurisprudence managed to balance the development of principles of law with sensitivity toward the member states. ${ }^{102}$ In interviews, CCJ judges explained that they were very conscious of not infuriating the member states at this early stage of institutionalization. ${ }^{103}$ The strategy they adopted-which consisted of establishing bold principles on topics such as access of private parties and member-state and Community liability, but without pecuniary consequences for the respondents-was effectively a form of "legal diplomacy."

Although this reflexive strategy of legal diplomacy allowed the CCJ to establish narrow authority as defined by Alter, Helfer, and Madsen, the claimants were not entirely content with the result. TCL was unsatisfied with the fact that it did not receive compensation, yet the company recognized that it had won the battle on the principle because the Court had created legal certainty on the procedure of suspension of the CET-a legal development of significant interest to the company, and other companies in the long run. ${ }^{104}$ Throughout the case the defendant, Guyana expressed its discomfort. ${ }^{105}$ The Guyanese government made it known that both the lawyer on the case, Dr. Claude Denbow, a Guyanese citizen himself, and Dr. Bertrand, the CEO of TCL, were considered undesirable persons on Guyanese territory-a consideration that some interpreted as close-to-death threats. ${ }^{106}$ Dissatisfied, Guyana also initially filed for an extension of the time to comply, which the CCJ rejected. ${ }^{107}$ This denial of extension prompted an application by TCL for noncompliance, which the CCJ rejected, making it very clear that Guyana was in violation of the Court's order. ${ }^{108}$ Guyana eventually complied with the judgment ${ }^{109}$ - most likely because of pressure from other CARICOM member states, although this cannot be confirmed. The CARICOM institutions involved in the cases, the Community and the Council for Trade and Economic Development, also exhibited some displeasure with their presence before the

European Court of Justice, 52 INT'L ORG. 121, 131 (1998).

102. See Mikael R. Madsen, The Protracted Institutionalization of the Strasbourg Court: From Legal Diplomacy to Integrationist Jurisprudence, in THE EUROPEAN COURT OF HUMAN RIGHTS BETWEEN LAW AND POLITICS 44, 49-51 (Mikael R. Madsen \& J. Christoffersen eds., 2011); Mikael R. Madson, Legal Diplomacy: Law, Politics and the Genesis of Postwar European Human Rights, in HuMAN

RIGHTS IN THE TWENTIETH CENTURY 62, 66 (Stefan-Lunwig Hoffman ed., 2011).

103. Interviews n. 3 (Oct. 21, 2013); n. 10 (Oct. 23, 2013); n. 16 (Oct. 25, 2013); n. 15 (Oct. 24, 2013).

104. Interviews n. 6 (Oct. 22, 2013); n. 19 (Oct. 26, 2013).

105. TCL v. Guyana, App. No. AR 1 of 2008 (Original Jurisdiction), Caribbean Court of Justice

[CCJ], II 17 (Jan. 15, 2009).

106. Interviews n. 6 (Oct. 22, 2013); n. 19 (Oct. 26, 2013).

107. TCL v. Guyana, App. No. OA of 2009 (Original Jurisdiction), Caribbean Court of Justice [CCJ], II 7 (Oct. 14, 2009).

108. TCL v. Guyana, Application No. OA 2 of 2009 (Original Jurisdiction), Caribbean Court of Justice [CCJ], II 4 (Mar. 29, 2010).

109. Justice Winston Anderson, Judge, Caribbean Court of Justice, Speech at the Regional Conference on "The Role of the Regional Courts in Strengthening Communitarian Law and Supra Nationality of the Process of Integration" (Jan. 30, 2014). 
Court. Indeed, the Secretary-General of CARICOM showed up in person to observe the proceedings-an action that many viewed as symbolic defiance. ${ }^{110}$ In conclusion, against the background of the TCL cases, it is clear the CCJ had only narrow authority in original jurisdiction proceedings at this stage. Cases were brought, and fought, mainly by a group of insiders to the system. ${ }^{111}$ Particularly because of the actions of President Jagdeo of Guyana, however, the Court received media attention and caused other key players, notably the Prime Minister of Jamaica, to argue publicly in favor of the CCJ. This publicity empowered the Court by reference to its already successful practices under appellate jurisdiction. Against this backdrop, the expansion of the Court's authority had only just begun.

\section{Broadening the Authority of the CCJ?}

In 2011, Humming Bird Rice Mills Ltd. filed cases against Suriname and the Community respectively. ${ }^{112}$ The company's allegations resembled those raised by TCL-in fact, at the initial stage of the case the lawyer representing TCL had been consulted. ${ }^{113}$ The cases alleged an unjustified suspension of the CET granted by the Community to Suriname on flour imported from the Netherlands. The CCJ found that Suriname had breached the RTC, yet it once again dismissed claims for damages. Interestingly, these two cases indicate that the TCL cases had the effect of attracting similar cases. Similarly notable, more claimants, and not only insiders to the system, also started approaching the CCJ under original jurisdiction at this point. Of the five cases filed between 2011 and 2014, two were filed by companies and three by individuals concerning their freedoms under the RTC. ${ }^{114}$ This slight but important change in the caseload

110. Interview n. 11 (Oct. 23, 2013).

111. In 2009, Doreen Johnson filed a labor-law case against the Caribbean Center for Development Administration. Johnson v. Caribbean Center for Development Administration, App. No. AR 2 of 2008 (Original Jurisdiction), Caribbean Court of Justice [CCJ] (Mar. 2, 2009). We have not included this case in the evaluation of the initial authority of the CCJ because it is an internal case to the organization of the Community of little relevance to outsiders.

112. The case led to three judgments: Hummingbird Rice Mills Limited v. Suriname, CCJ Application of No. OA 1 of 2011 (Original Jurisdiction), Caribbean Court of Justice [2011] CCJ 1 (OJ) (June 27, 2011); Hummingbird Rice Mills Limited v. Suriname, CCJ Application of No. OA 1 of 2011 (Original Jurisdiction), Caribbean Court of Justice [2012] CCJ 1 (OJ) (Feb. 23, 2012); Hummingbird Rice Mills Limited v. Suriname, CCJ Application of No. OA 1 of 2011 (Original Jurisdiction), Caribbean Court of Justice [2012] CCJ 2 (OJ) (Apr. 11, 2012).

113. Ultimately, two other lawyers-Mr. Elvis O'Connor and Ms. Linda Greene_argued the case. Interviews n. 17 (a) and (b) (Oct. 25, 2013).

114. These were, in order of filing: Hummingbird Rice Mills Limited v. Suriname, CCJ Application of No. OA 1 of 2011 (Original Jurisdiction), Caribbean Court of Justice [2011] CCJ 1 (OJ) (June 27, 2011); Myrie v. Barbados, App. No. OA 002 of 2012 (Original Jurisdiction), Caribbean Court of Justice [2012] CCJ 3 (OJ) (Sept. 27, 2012); Rudisa Beverages \& Juices N.V. and Caribbean International Distributors Inc. v. The Co-operative Republic of Guyana, App. No. OA 003 of 2013 (Original Jurisdiction), Caribbean Court of Justice [2014] CCJ 1 (OJ) (May 8, 2014); Tomlinson v. Belize, App. No. OA 1 of 2013 (Original Jurisdiction), Caribbean Court of Justice [2014] CCJ 2 (OJ) (May 8, 2014); Tomlinson v. Trinidad \& Tobago, App. No. OA 2 of 2013 (Original Jurisdiction), Caribbean Court of Justice [2014] CCJ 2 (OJ) (May 8, 2014). 
coincided with attempts to broaden CCJ authority. To analyze this development, this article analyzes the appointment of a new Court President, the landmark case of Myrie v. Barbados ${ }^{115}$ and its reception in the broader legal and political field in which the CCJ operates, and the three recent cases filed before the Court by individuals.

These changes were spurred by the arrival of a new President to the Court. Whereas de la Bastide had been central to establishing the Court and its initial narrow authority in a highly complex legal and political environment, the new President, Sir Dennis Byron, sought to take the Court to new levels by widening the scope of its jurisdiction-notably with regard to individuals' rights under the RTC. ${ }^{116}$ Like his predecessor, Byron's professional trajectory represented the counter narrative to the post-colonial standard argument that locals could not provide the level of knowledge and experience of those lawyers trained in London. Not only had Byron established himself at the United Nations, but he had also established himself in the heart of post-colonial law: the Privy Council. Byron brought significant national and international judicial experience; he was former Chief Justice of the Eastern Caribbean Supreme Court and President of the United Nations International Criminal Tribunal for Rwanda. In addition to his significant judicial experience, Byron had the credentials of the old Caribbean legal elite. He graduated from Cambridge, was called to the bar of the Inner Temple before pursuing private practice with chambers in Saint Kitts \& Nevis and Anguilla (1966-1982), and was appointed to the Privy Council in 2004. Furthermore, Byron had also made a name for himself as a judicial reformer, both in the Caribbean and the Commonwealth, with a focus on ethics and case management.

The Byron Court was offered an early chance to leave its mark on the CCJ in 2012, when Shanique Myrie, a Jamaican national, filed a case alleging that (1) the state of Barbados had violated her right to freedom of movement within the Community $^{117}$ and (2) the behavior of the Barbadian border officers-who conducted a cavity search on her, detained her overnight in a cell at the airport in Bridgetown, and repeatedly insulted her-constituted a serious violation of her rights as a CARICOM citizen. ${ }^{118}$ Further fuel was added to the case when the Court granted Jamaica leave to intervene as a third party. CARICOM also intervened in the case, this time not as a defendant, but with a pro-Community and pro-CCJ attitude, which took Barbados by surprise. In deciding the case, the Court abandoned the constraining strategy of legal diplomacy consistent with the de la Bastide Court and instead adopted a more assertive line of argument aimed at expanding the CCJ's jurisdiction and transforming

115. Myrie, App. No. OA 002 of 2012 (Original Jurisdiction).

116. Interview n. 1 (Oct. 21, 2013).

117. As protected by the Article 45 RTC and by a Decision of the Conference of the Heads of Government of the Caribbean Community taken at their Twenty-Eighth Meeting (2007 Conference Decision).

118. Myrie, App. No. OA 002 of 2012 (Original Jurisdiction), II 2. 
CARICOM from a mere collection of sovereign States to a united political community with an autonomous legal order. ${ }^{119}$ Thereby, the Myrie case offered an entrée for basic constitutional principles of European Union law into Caribbean law and politics.

On the merits, the Court first found Barbados in violation of the RTC. It also ordered Barbados to pay compensation to Ms. Myrie as reparation for the breach of her right to freedom of movement, signaling for the first time the Court's willingness to award damages under its original jurisdiction. ${ }^{120}$ Second, the Court employed well-crafted legal reasoning that resembled the jurisprudence of the ECJ to cement the Caribbean legal order by roughly establishing the principles of supremacy and the direct effect of CARICOM Community law. More specifically, the Court recognized the legal validity of the 2007 Conference Decision, which was not formally part of the RTC and was not legislatively enacted by any of the member states. ${ }^{121}$ The CCJ's reasoning echoed that of the ECJ in Costa v. Enel ${ }^{122}$ on the supremacy of Community law:

The RTC ... and more particularly the 2007 Conference Decision brought about a fundamental change in the legal landscape .... Although it is evident that a State with a dualist approach to international law sometimes may need to incorporate decisions taken under a treaty and thus enact them into municipal law in order to make them enforceable at the domestic level, it is inconceivable that such a transformation would be necessary in order to create binding rights and obligations at the Community level.... . If binding regional decisions can be invalidated at the Community level by the failure of the part of a particular State to incorporate those decisions locally the efficacy of the entire CARICOM regime is jeopardized and effectively the States would not have progressed beyond the pre-2001 voluntary system that was in force.

The Court's reasoning thus equated the decisions of the Conference to the norms entrenched in the RTC. Consequently, the Court effectively created secondary legislation directly applicable at the Community level and hierarchically superior to national laws.

Third, the Court came close to establishing a principle of direct effect using phrases resonant of the ECJ in Van Gend en Loos. ${ }^{124}$ The Court stated: "[T]he very idea and concept of a Community of States necessarily entails as an exercise of sovereignty the creation of a new legal order and certain selfimposed, albeit perhaps relatively modest, limits to particular areas of State sovereignty." ${ }^{125}$ Of course, one can argue that the CCJ's interpretation of Caribbean Community law reflected here is mainly limited to the Community level and does not directly raise issues of domestic embeddedness in ways

119. Id. II $17-10$.

120. The Court, however, rejected the claims related to the violation of Ms. Myrie's human rights for lack of jurisdiction. Id. II 10.

121. The Caribbean States follow the dualistic doctrine of international law, according to which international treaties have no effect domestically unless they are converted into national law by an act of the legislative branch.

122. Case 6/64, Flaminio Costa v. ENEL, 1964 E.C.R. 585.

123. Myrie, App. No. OA 002 of 2012 (Original Jurisdiction), III 50-52.

124. Case 26-62, Van Gend \& Loos v. Netherlands Inland River Administration, 1963 E.C.R. 2.

125. Myrie, App. No. OA 002 of 2012 (Original Jurisdiction), II 69. 
similar to European Union law. The CCJ's direct effect doctrine is limited in applicability and follows from the binding nature of international law on states and the "correlative rights" ${ }^{26}$ it establishes for individuals. Although these rights can now be activated at the Community level when private litigants file suits directly with the $\mathrm{CCJ}$, the Court has yet to make the rights directly enforceable by national judges. In other words, the contours of the framework are in place for an ECJ-style direct effect, but they have yet to be fully established. ${ }^{127}$

What is probably more significant than the CCJ's direct effect doctrine is the wide attention the Myrie case received in the public and in the legal field. ${ }^{128}$ The case strongly indicated the CCJ's broadening authority and suggested that the CCJ was not simply another venue for large business but also a Court securing the rights of individual Caribbean citizens. As the title of an op-ed published in the wake of the CCJ's Myrie decision read, "[the] Caribbean Court of Justice delivers for the Caribbean's people." ${ }^{129}$

Particularly in Jamaica, the home country of Myrie, the case was promoted as support for ending the appeals to the JCPC, regardless of the fact that it did not concern appellate jurisdiction..$^{130}$ In the Caribbean legal field more generally, the case also received attention. In a personal letter to the President of the CCJ, one of the Caribbean's legal "dinosaurs" of the traditional transatlantic configuration applauded the decision's overall quality and importance (although he also added that it violated basic principles of English international law). He wrote,

[A] lot of thought must have been invested in the process to produce a judgment of a standard that we might all be proud of. It is not only meticulously prepared but extremely well-reasoned ... I take positively the direction of the judgment as the most significant act of integration since the creation of the Federation.

Legal academia from the UWI campus equally mobilized in the wake of the case. In fact, Professor Berry, the leading authority on Community law and Dean of the UWI Law Faculty, had been part of the legal team that defended Barbados. ${ }^{132}$ Most notably, the case incited in academia a new stage of

126. The CCJ established the principle of "correlative rights" in the case between TCL and Guyana. See supra note 75.

127. Cf. BERRY, supra note 35, at 211.

128. The newspaper "The Jamaican Observer" published a series of articles both to the case and to the subsequent difficulties of Ms. Myrie of getting her damages paid by Barbados. But all major newspapers have published news items on the matter. See Barbados Yet to Pay Shanique Myrie, JAMAICA OBSERVER (Jan. 3, 2014), http://www.jamaicaobserver.com/news/Barbados-yet-to-payShanique-Myrie_15726998.

129. Ronald Sanders, Caribbean Court of Justice Delivers for the Caribbean's People, KAIETEUR NEws (Jamaica) (Oct. 13, 2013), http://www.kaieteurnewsonline.com/2013/10/13/caribbean-court-ofjustice-delivers-for-the-caribbeans-people/.

130. A survey of online newspapers during the period finds similar arguments in a number of Caribbean countries.

131. Interview n. 1 (Oct. 21, 2013).

132. Myrie v. Barbados, App. No. OA 002 of 2012 (Original Jurisdiction), Caribbean Court of Justice [2012] CCJ 3 (OJ) (Sept. 27, 2012); Interview n. 24 (Oct. 31, 2013). 
scholarship on Caribbean law. Whereas earlier scholarship had been dominated by more promotional writings, Myrie inspired numerous conferences of a more empirical nature. The case also coincided with the 2014 publication by Professor Berry of the first manual on Caribbean integration law with Oxford University Press. ${ }^{133}$ This was yet another sign that this field of law was to be taken seriously.

Above all, it is important to highlight that Barbados, although certainly not happy with the outcome of the case, did not explicitly challenge the authority of the Court. In an interview, the Attorney-General of Barbados stated that he disagreed only with the assessment of the facts conducted by the Court, not with the CCJ's jurisdiction to decide the issue or the accuracy of the Courtestablished principles. ${ }^{134}$ The Attorney-General noted, "[T]his is litigation. One time you lose, next time you win. ${ }^{135}$ Moreover, after several months of false promises, delays, and discussions with the Jamaican authorities accompanied by numerous newspaper articles, Barbados eventually complied with the judgment and paid the damages granted to Myrie by the CCJ ${ }^{136}$ However, closer scrutiny of government statements, particularly Trinidad \& Tobago and Barbados in relation to the case-and the provocation of their Jamaican counterpartssuggests that the intermediate authority of the CCJ is not a fait accompli. In fact, scorching remarks from one Trinidad \& Tobago Minister in December 2013 on the undesirability of Jamaicans in Trinidad caused significant uproar in the region and created an opposition between host and home countries of free movers, a problem well known to scholars of European integration. ${ }^{137}$

The Myrie case marked the beginning of a wider acceptance of the CCJ as an authoritative adjudicator of Caribbean law particularly in the public and legal fields. Although the member states on the receiving end of free movement clearly stated their reservations, CARICOM had intervened for the first time in favor of a complainant. A different indicator of the broadening of authority provoked by Myrie was the arrival of several new cases to the Court-one on Community law filed by a company ${ }^{138}$ two on individual rights filed by a Jamaican citizen against Belize and Trinidad and Tobago, ${ }^{139}$ and some politically sensitive appellate jurisdiction cases. ${ }^{140}$ In the Rudisa Beverages case, two

133. BERRY, supra note 35.

134. Interview n. 28 (Nov. 6, 2013).

135. Id.

136. Shanique Myrie Paid by Barbados Government, JAMAICA OBSERVER (June 24, 2014), http://www.jamaicaobserver.com/news/Shanique-Myrie-paid-by-Barbados-Government_16996057.

137. See, e.g., O'Leary Siofra, Free Movement of Persons and Services, in THE EvOLUTION OF EU LAW 499, 512-13 (Paul Craig \& Grainne De Burca eds. 2011).

138. Rudisa Beverages \& Juices N.V. and Caribbean International Distributors Inc. v. The Cooperative Republic of Guyana, App. No. OA 003 of 2013 (Original Jurisdiction), Caribbean Court of Justice [2014] CCJ 1 (OJ) (May 8, 2014).

139. Tomlinson v. Belize, App. No. OA 1 of 2013 (Original Jurisdiction), Caribbean Court of Justice [2014] CCJ 2 (OJ) (May 8, 2014); Tomlinson v. Trinidad \& Tobago, App. No. OA 2 of 2013 (Original Jurisdiction), Caribbean Court of Justice [2014] CCJ 2 (OJ) (May 8, 2014).

140. British Caribbean Bank Ltd. v. Belize, App. No. CV 001 of 2013 (Appellate Jurisdiction), Caribbean Court of Justice [CCJ] (June 25, 2013); Raju Meenavalli v. Georgia and Janae Matute, App. 
companies claimed that the imposition by Guyana of an environmental levy, or tax, on all nonreturnable beverage containers imported to that country constituted a violation of the RTC. In 2014, the CCJ decided on the merits of the case and, importantly, condemned Guyana to pay compensation to the two companies because it considered the imposition of those taxes contrary to the RTC. ${ }^{141}$ The two cases on fundamental rights are closely connected. In both, the applicant, Maurice Arnold Tomlinson, a Jamaican gay rights activist, seeks to strike down the Immigration Acts of both Belize and Trinidad \& Tobago, which prohibit the entrance of homosexuals to their respective countries. ${ }^{142}$ The CCJ has granted leave in both cases and proceedings are pending. ${ }^{143}$ As concerns the appellate cases, it is worth mentioning the Maya Leaders Alliance et al. v. the Attorney General of Belize, a case dealing with a highly political and longlasting dispute related to land rights between the Government of Belize and some Mayan minorities.

These new cases confirm the general trend of the Court's broadening authority, a clear expansion beyond the initial narrow, litigant-specific authority. The Rudisa Beverages case confirms that the TCL was not a one-shot decision; TCL remains relevant to a pool of Pan-Caribbean companies that have an interest in the court as the primary enforcer of the RTC. Above all, this case signals the Court's transition to a more liberal view on damages, a view which may have particular significance to private business litigants.

The two Tomlinson cases equally indicate the Court's emerging intermediate authority. According to interviewees, the cases are not simply an individual initiative but rather the result of an organized campaign on gay rights involving the Rights Advocacy Project of the Jamaican Faculty of Law of the UWI and Tomlinson himself as an activist and lawyer. ${ }^{144}$ The widening acceptance of the Court's authority is further evidenced by the submissions for special leave by both Belize and Trinidad \& Tobago in the Tomlinson cases. The two countries did not challenge the jurisdiction of the Court. To the contrary, they first recognized the binding principles on private access established by the Myrie case, and, secondly, they stated that the two contested Immigration Acts-although in principle prohibiting entry of homosexuals-are not applied in practice. ${ }^{145}$ The Court responded by granting leave, noting, in line with decisions from other human rights systems, that there is an arguable case because the mere existence of the legislative provisions in question amounts to

No. CV 4 of 2012 (Appellate Jurisdiction), Caribbean Court of Justice [CCJ], (Apr. 10, 2014); The Maya Leaders Alliance et al. v. The Attorney General of Belize, App. No. BZCV2014/002 (Appellate Jurisdiction), Caribbean Court of Justice [CCJ], (Oct. 30, 2015).

141. Rudisa Beverages, App. No. OA 003 of 2013 (Original Jurisdiction), II 29.

142. On May 8, 2014, he was granted leave by the CCJ, and the case is now proceeding. On the same day, the CCJ ruled in favor of Rudisa Beverages \& Juices N.V. Caribbean International Distributors, Inc. and against Guyana. Id.

143. Tomlinson, App. No. OA 1 of 2013 (Original Jurisdiction).

144. Interview n. 12 (Oct. 24, 2013).

145. Tomlinson, App. No. OA 1 of 2013 (Original Jurisdiction), II 2. 
prejudice. ${ }^{146}$ Although the two cases are therefore generally suggestive of the Court's intermediate authority, the cases are also viewed by many as potentially explosive $^{147}$ To these critics, the Court risks the reverse effect of a backlash because such a holding could potentially incite a clash of international human rights and local cultural sensitivities - a clash similar to the conflict over death row. Moreover, if the CCJ chooses to repel the domestic laws of Trinidad and Tobago and Belize, the Court is effectively establishing a power of judicial review that might come as a surprise to some of the member states. Finally, the Maya appellate case, in which the Court condemned Belize to pay BZ\$300.000.00 for the violation of customary land tenure of some Mayan communities, reveals the ability and the willingness of the Court to present itself as the Court of Caribbean peoples and venture into questions of human and indigenous rights.

IV

\section{CONCLUSION}

Although the total number of cases under the CCJ's original jurisdiction remains very limited, these recent developments clearly suggest an evolution of the Court toward intermediate authority under the Alter, Helfer, and Madsen framework. ${ }^{148}$ Above all, this burgeoning of authority is indicated by the caseflow, the broadening of the pool of applicants, and the broader popular interest in the CCJ that has expanded beyond the fields of law and politics. Following the key decisions on private access and state liability (TCL), the balanced handling of capital punishment (Joseph and Boyce), and the new jurisprudence on damages (Rudisa Beverages), Myrie added a further dimension to the small but evolving jurisprudence on Community law, which indicatively seems to continue in the recent Tomlinson cases. When considered in light of the Court's protracted genesis and its background in two different and conflicting trajectories of Caribbean integration through law, the Myrie case created an intersectional constituency, one that, first, involves both citizens' rights and the rights of private businesses and, second, enables the CCJ to bypass the social, legal, and political divisions that have long hampered Caribbean integration. This has also increasingly made the CCJ the "Caribbean peoples' court"-a major development in and of itself considering the traditional elitist construction of law in the region. The CCJ's recent direction suggests that it may seek to move toward an increasing convergence of its two different jurisdictions and operational contexts. Major judgments under the appellate jurisdiction are increasingly becoming regional news, an example being a recent case involving a malpractice lawsuit against a Belizean doctor ${ }^{149}$ which is

146. Id. II 6 (citing case law of the European Court of Human Rights and the United Nations Human Rights Committee).

147. Interview n. 1 (Oct. 21, 2013).

148. Alter, Helfer \& Madsen, supra note 7.

149. Meenavalli v. Matute, App. No. CV 4 of 2012, Caribbean Court of Justice [2014] CCJ 8 (AJ) 
strongly suggestive of this convergence. ${ }^{150}$ Moreover, the extensive authority of the CCJ under appellate jurisdiction-although such authority only applies to four countries-seems to fuel the overall authority of the Court. The recent Maya case is further evidence of that.

Generally, indications of intermediate authority are in place, but the turn and mobilization of people-individual and corporate-should not overshadow the fact that many governments and legal professionals are still reluctant to engage the CCJ. Among legal and political elites, the transnational configuration of law-with the JCPC at the apex-is still widely popular and invoked to argue against accepting appellate jurisdiction. However, these elites generally have much less to add on original jurisdiction because they possess less expert knowledge in community law. The constitutional amendment procedures needed in some states for replacing the JCPC with the CCJ also make the transition to the CCJ very difficult. Ironically, while this situation of stalemate was cemented by the JCPC, that court's judges have recently toured the Caribbean to discretely argue for abolition of appeals from the Caribbean to the JCPC. The English judges feel constrained by the Caribbean cases and seek to concentrate on the new U.K. Supreme Court. ${ }^{151}$ Jamaica and a number of smaller Caribbean states are also actively seeking to abolish the JCPC, which is equally indicative of the CCJ's overall authority in the region. Moreover, notwithstanding reluctance in some countries, notably Trinidad \& Tobago and Guyana, all states have so far taken meaningful steps toward the implementation of judgments against them. There is, however, a new split among the CARICOM member states on the issue of regional integration. While the more prosperous states such as Trinidad \& Tobago and Barbados caution against being overrun by immigrants from the poorer states under free movement, states such as Jamaica have become very active defenders of the rights to free movement. These splits are potentially politically critical to further integration under CARICOM, but they do not, in light of this analysis, change the fact that the CCJ generally has intermediate authority.

(Apr. 10, 2014).

150. There is also a significant growth in the number of appellate cases. See CCJ Reports Increased Judgments in Appellate Jurisdiction, JAMAICA OBSERVER (June 25, 2014), http://www.jamaicaobserver .com/news/CCJ-reports-increased-judgments-in-appellate-jurisdiction_1699 8748.

151. Privy Council's Complaint, BBC CARIBBEAN (Sept. 24, 2009), http://www.bbc.co.uk/caribbean /news/story/2009/09/090922_privyccjphillips.shtml. 